\title{
Factory-mounted and Retrofit Passive Resistance Sensors Adapted to Monitor Moisture Content in Timber Bridges
}

\begin{abstract}
Niclas Björngrim, ${ }^{\mathrm{a}, *}$ Per-Anders Fjellström, ${ }^{\mathrm{b}}$ and Olle Hagman ${ }^{\mathrm{a}}$
The biggest threats to the longevity of a timber bridge are rot and decay. Wood protection by design, inspections, and monitoring of the bridge for elevated moisture content will ensure that the full service life of the structure can be achieved. Today's sensors for moisture content measurements are limited in their functionality and range. This paper presents a sensor that can be both factory installed and retrofitted, which can measure the moisture content through the cross-section of the member in a timber bridge. The sensor has been mounted on Sundbron bridge during manufacturing and retrofitted on Gislaved bridge. The ensuing measurements helped to adjust a design flaw on Gislaved bridge. Monitoring of Sundbron showed that the bridge deck dried up after the bridge had been exposed to sleet and snow during the on-site assembly of the stress laminated bridge deck.
\end{abstract}

Keywords: Timber bridge; Wood sensors; Timber bridge monitoring; Moisture content sensor

Contact information: a: Luleå University of Technology, SE-931 87, Skellefteå, Sweden; $b$ : Science

Partner, Laboratorgränd 2, SE- 931 62, Skellefteå, Sweden;

*Corresponding author: niclas.bjorngrim@ltu.se

\section{INTRODUCTION}

Bridges built in Sweden today have a required service life of either 40 years, 80 years, or 120 years (Anon 2004). The service life depends on the intended traffic and length of the bridge. Most timber bridges have a required service life of 80 years. The biggest threat to the service life is elevated moisture content (MC) levels in the wood. When the MC reaches over $20 \%$, mold can attack the timber. For decay fungi to develop, the relative humidity (RH) must be over $95 \%$ and the MC over $25 \%$, at temperatures between 0 and 45 ${ }^{\circ} \mathrm{C}$ (Viitanen 1994). The MC also affects the mechanical properties of wood up to the fiber saturation point, circa 28\% MC for Norway spruce. An increase in MC decreases the mechanical properties (Ross 2010). Fjellström and Just (2017) presented the results from inspections of 17 Estonian bridges; one of the bridges was poorly designed and poorly maintained and showed decay so severe after six years of use, that it was demolished. High $\mathrm{MC}$ on the bottom of the timber bridge deck can lead to cupping of the deck. Swedish timber bridges are built with untreated spruce, because chemical treatments come with various environmental concerns. To ensure the full service-life of the bridge is reached, wood protection by design is used, and in-depth inspections are performed every six years. MC sensors can be a valuable complement to the two aforementioned processes. By measuring the MC at key points; the ends of the bridge decks, close to connections and attachments, etc., the performance of the protection can be verified and give important data to bridge inspectors. Figures 1 through 3 show examples of rot and cupping from in-depth inspections of bridges. 


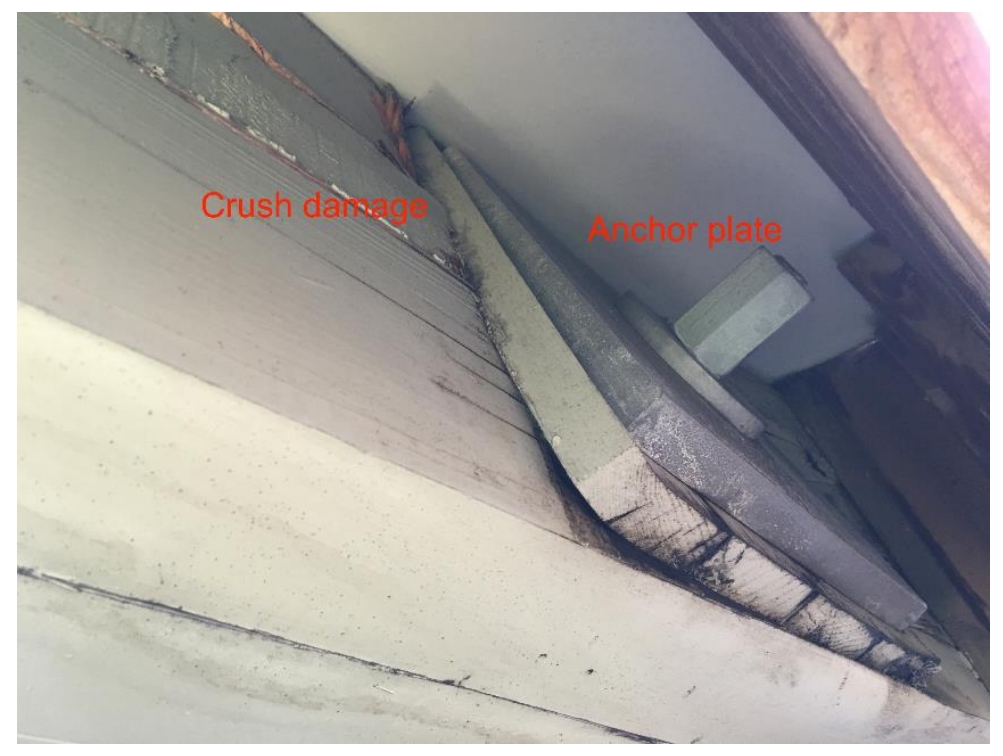

Fig. 1. Anchor plate crushing a rotten glulam beam

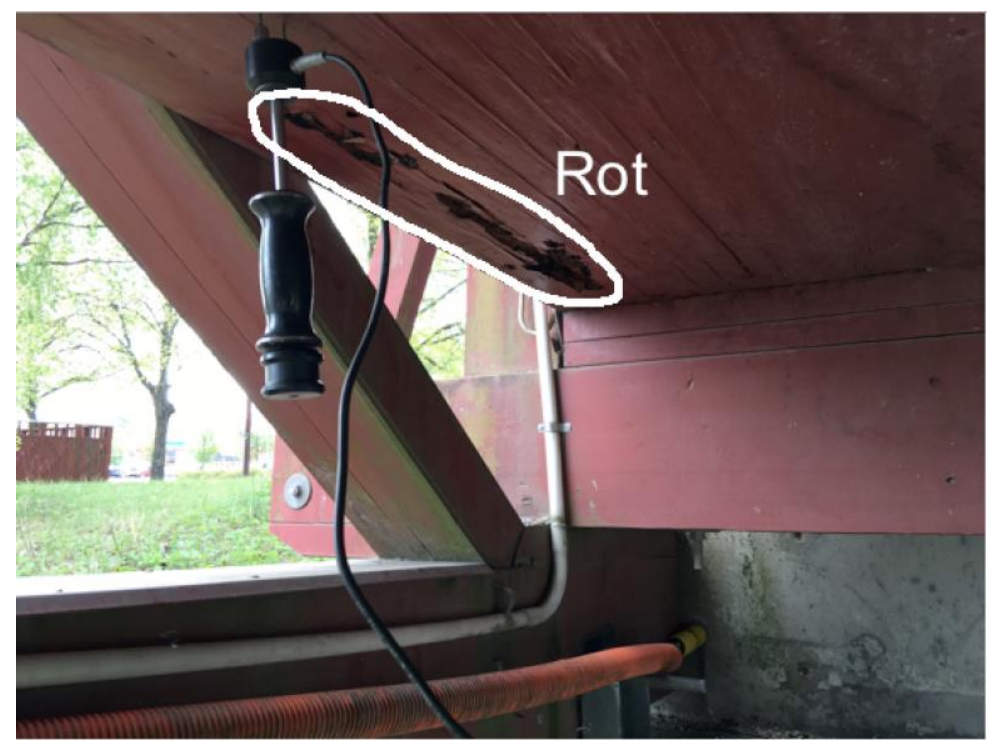

Fig. 2. The bottom of a pedestrian bridge with severe decay shown in the outer beam

The reason for rot can often be construction error: the waterproofing membrane, the rail post attachment, or where the drip edge is attached to the bride deck, etc. These errors all result in an available entrance for water into the stress-laminated deck. Collision damage and damage to the waterproofing membrane could also eventually lead to rot. Usually, moisture problems in stress-laminated bridge decks are found in the two outer glulam-beams. The sensor technology currently used is not suitable for measuring at these vulnerable points. There are several sensors for measuring moisture content in the timber constructions on the market. Typically, the sensors are screwed in and measure the resistance between the screws. The resistance can then be used to calculate the MC. One example of a bridge equipped with such a system can be found in Björngrim et al. (2016). Tannert et al. (2010) used resistance sensors mounted in the glulam along the height of the cross-section. Dyken and Klepp (2010) used humidity sensors to determine the MC from 
the relative humidity readings. One thing in common across all methods is that they measure a very limited area of a few locations in the cross-section. Björngrim et al. (2017) have presented a model to measure the MC from a modified resistance measurement, using uninsulated electrodes. The model incorporates a calibration for the length of the uninsulated electrode and the timber temperature. This paper uses that model to calibrate a passive resistance sensor that can measure the MC along the height of the cross-section in an arch, girder, or stress-laminated deck, etc. The sensor has been installed on two bridgesone at the factory, and one retrofitted on site.

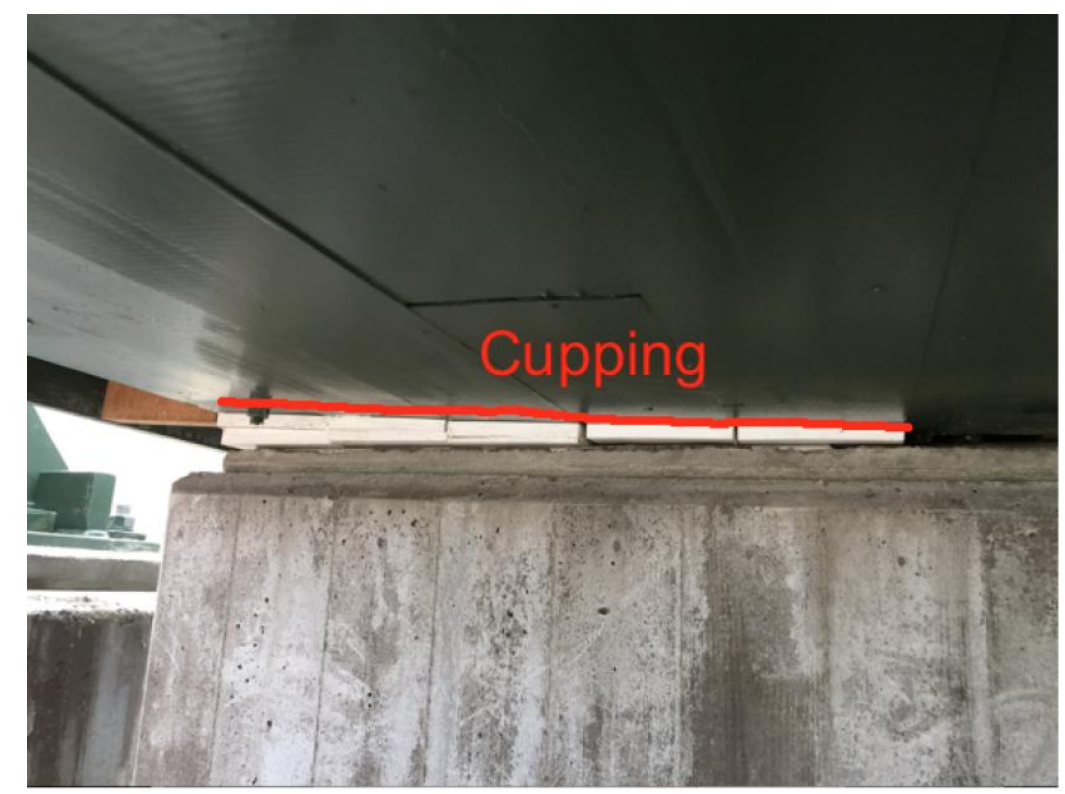

Fig. 3. Cupping of a stress laminated bridge deck, the white wedge have been inserted afterwards to give full contact between abutment and deck.

\section{EXPERIMENTAL}

\section{Materials}

The construction of the sensor is simple, robust, scalable, and based on proven method-resistance measurements. The simplicity and material choice ensured long-term functionality. The fixed installation of the sensor ensured good repeatability of the measurements. The sensor consisted of three uninsulated stainless steel electrodes clamped between two glulam beams or pushed into drilled holes.

In Fig. 4, the schematics of the sensor are shown. Before the electrodes are clamped between two glulam beams, they are stapled on to the surface of one of the glulam beams to stay in place. The three electrodes give two measurement points, one close to the bottom of the bridge deck and one that measures from the middle to right below the top of the bridge deck. Measurement point 1 (MP1) uses the $45 \mathrm{~mm}$ long left electrode, and the middle electrode which is $20 \mathrm{~mm}$ shorter than the height of the bridge deck, to measure the lowest resistance from the bottom of the bridge deck to a depth of $45 \mathrm{~mm}$. 


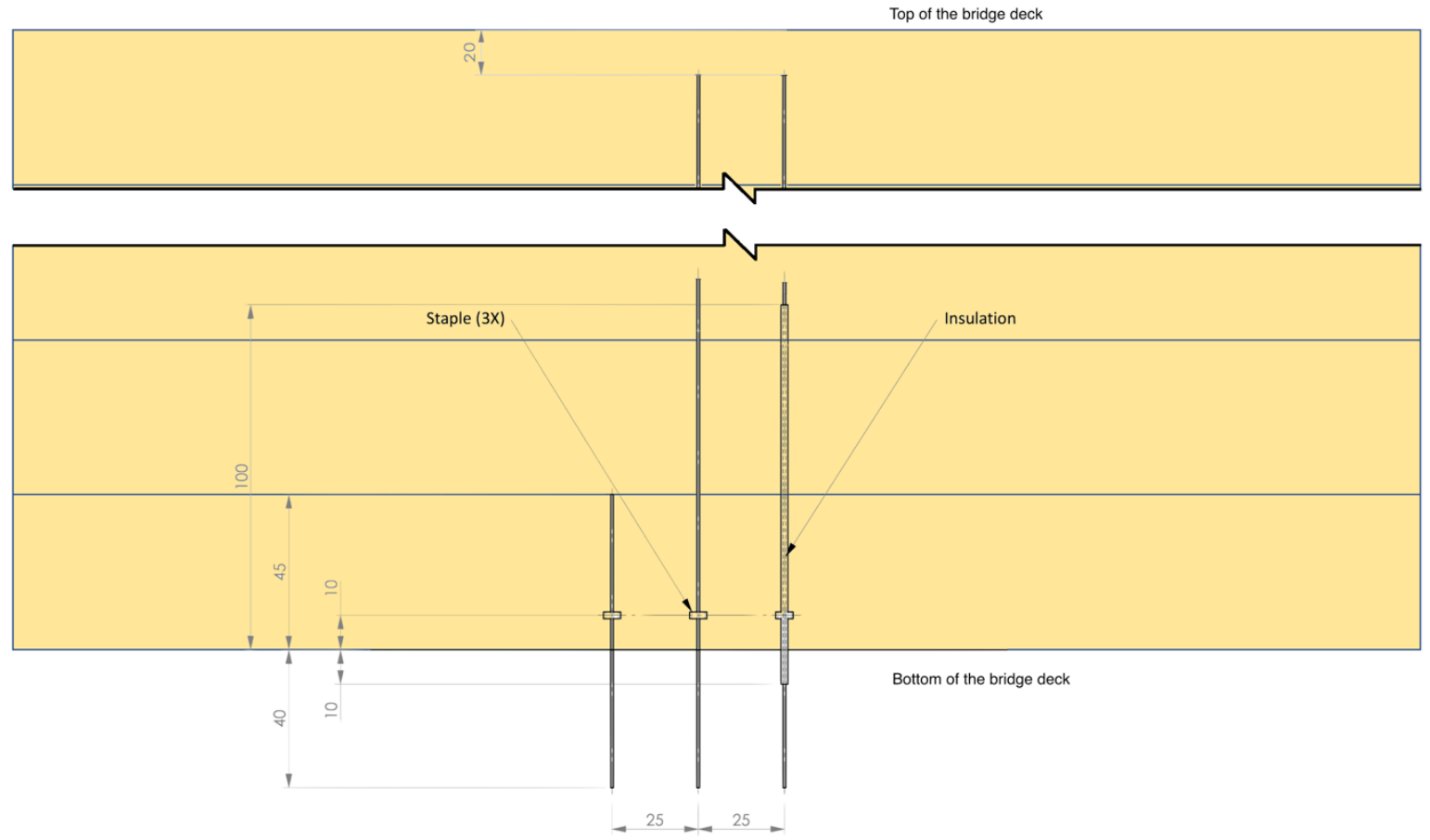

Fig. 4. Schematics of the sensor: three electrodes making two measurement points, one close to the bottom of the deck, and one for the middle and top of the deck. All measurements are in millimeters.

Measurement point 2 (MP2) consisted of the right and middle electrode, where the right electrode is isolated with shrink tubing for the first $100 \mathrm{~mm}$. The MP1 will measure the lowest resistance from the end of the isolation to the end of the electrode, $20 \mathrm{~mm}$ below the top of the bridge deck. The lowest resistance measured answers to the highest MC. The factory mounted sensors used stainless steel wire with a diameter of $0.75 \mathrm{~mm}$ for the electrodes. For the retrofitting, stainless steel electrodes with a diameter of $2.4 \mathrm{~mm}$ were pushed into the drilled holes. Each bridge also had two thermocouples installed, one on the south facing side and one on the north facing side. The thermocouples are located $25 \mathrm{~mm}$ to the left from the short electrode and $100 \mathrm{~mm}$ from the bottom. The ends of the electrodes were collected by push-in wire connectors and connect to a terminal block. The wires are zinc coated to ensure the sensor will last as long as the service life of the bridge. An IP 65 classed junction box protects the sensor from the elements (see Fig. 5). Resistance measurements were then made with a standard Delmhorst moisture meter (Delmhorst Instrument Company, Towaco, NJ, USA), with a connector fitting the terminal block. The resistance data acquired was then converted to a MC\% using two formulas (Björngrim et al. 2017) for the two electrode lengths. 


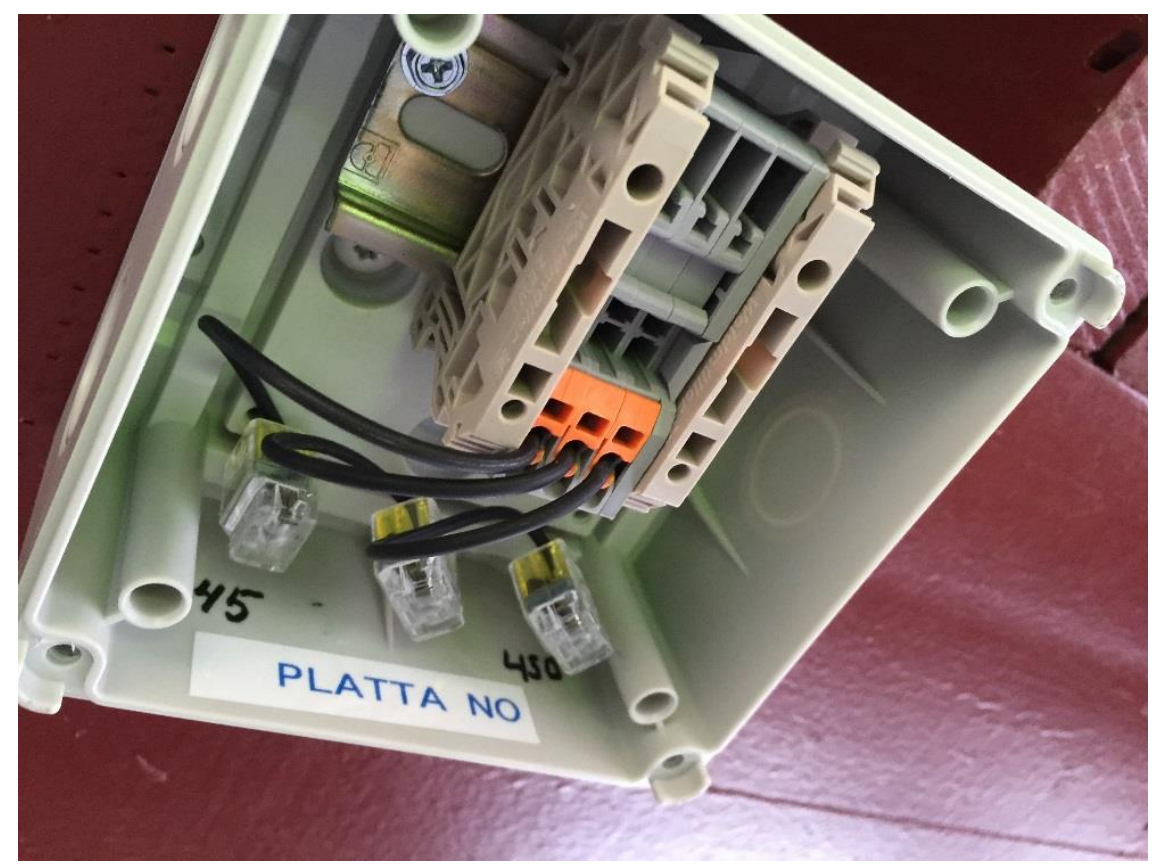

Fig. 5. The sensor mounted on the bottom of a bridge deck

\section{Methods}

The Sundbron Bridge

Located in Boden (Sweden), Sundbron is a stress-laminated, one-lane traffic bridge. The bridge is four meters wide and 26 meters long, and was erected in November 2015. The bridge spans across a narrow between two lakes.

At the end of the construction phase, Sundbron was equipped with passive sensors at the bridge factory. The sensors were clamped between the first and second glulam beam and transported as a unit to the bridge site. Sundbron has seven MC sensors and two thermocouple measuring the temperature of the bridge deck.

Figure 6 shows the sensor placement. Sensors 2 and 3 were wired to the junction box for sensor 4, allowing sensors under the span to be measured. Analogously, sensor 6 was wired to the junction box for sensor 6 . The thermocouples are located at 1 and 7.

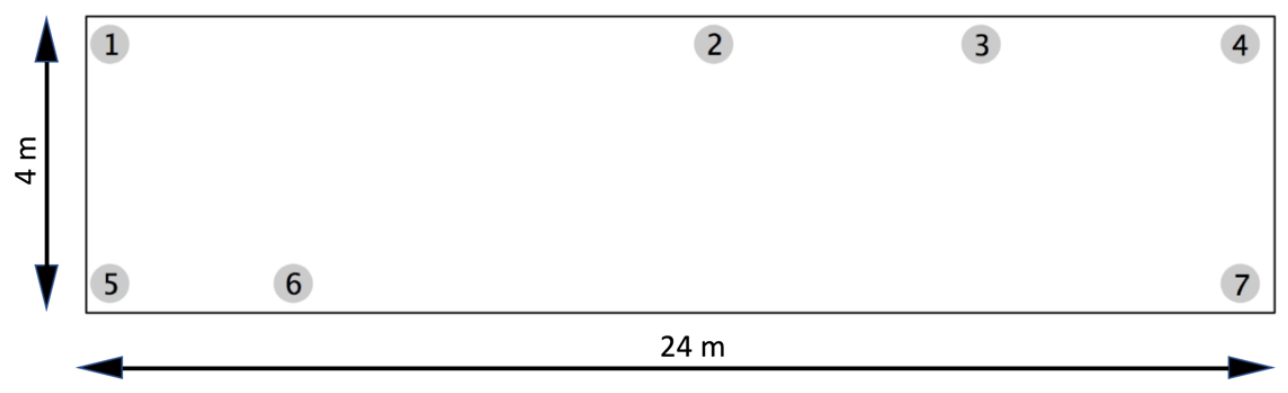

Fig. 6. Schematic top view of the bridge deck of Sundbron Bridge, the locations of the seven sensors are shown. 


\section{The Gislaved Bridge}

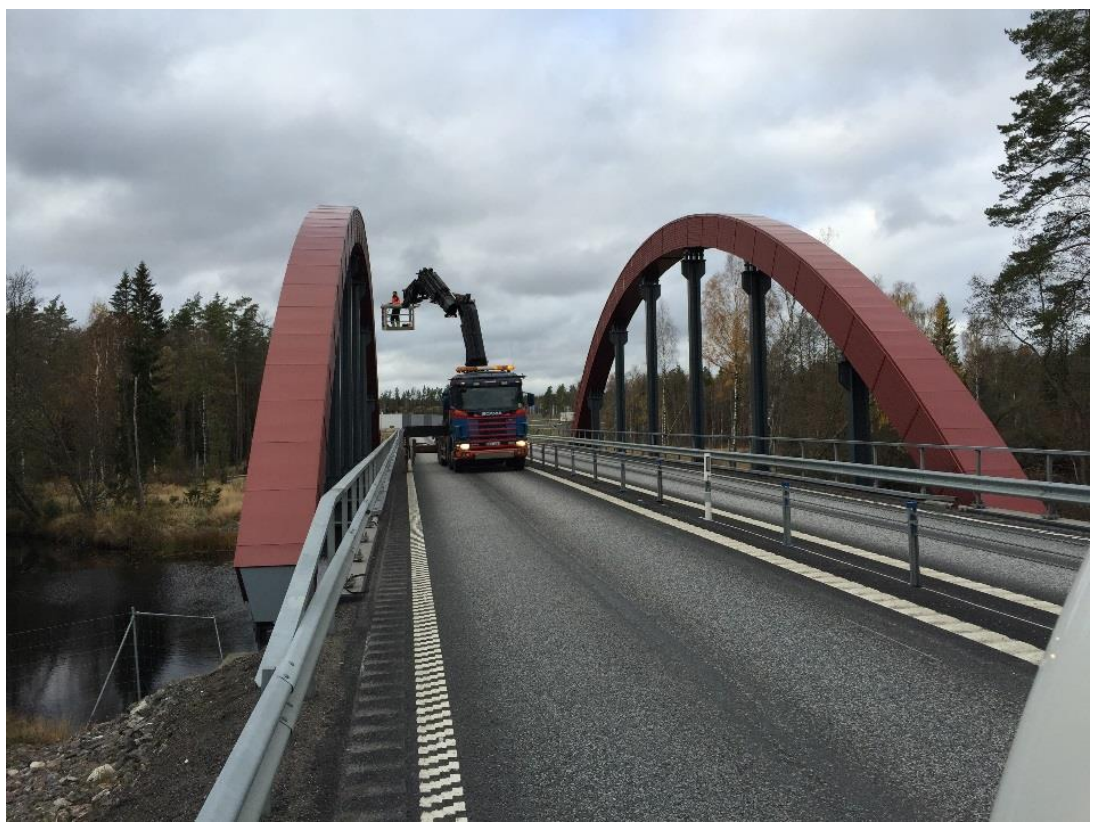

Fig. 7. Mounting a sensor on the south arch from the aerial work platform

The Gislaved Bridge is an arch bridge with two lanes for highway traffic, at speeds up to $110 \mathrm{~km} / \mathrm{h}$. The bridge spans 46 meters and the deck is 10.5 meters wide. The deck is made of stress laminated timber and the arches of glulam. The bridge spans across the Nissan River and is the longest bridge for highway traffic in Sweden. The bridge was erected in October 2013.

The bridge was retrofitted with $16 \mathrm{MC}$ sensors and two thermocouples. Figure 8 shows the location of the sensors; the thermocouples are installed at location 4 and 13. The process of attaching the cables for the sensor wires and installing the sensors on the Gislaved Bridge was completed in two days. To reach the arches and the bottom of the bridge, an aerial work platform was used. The work required the closure of one lane each day.

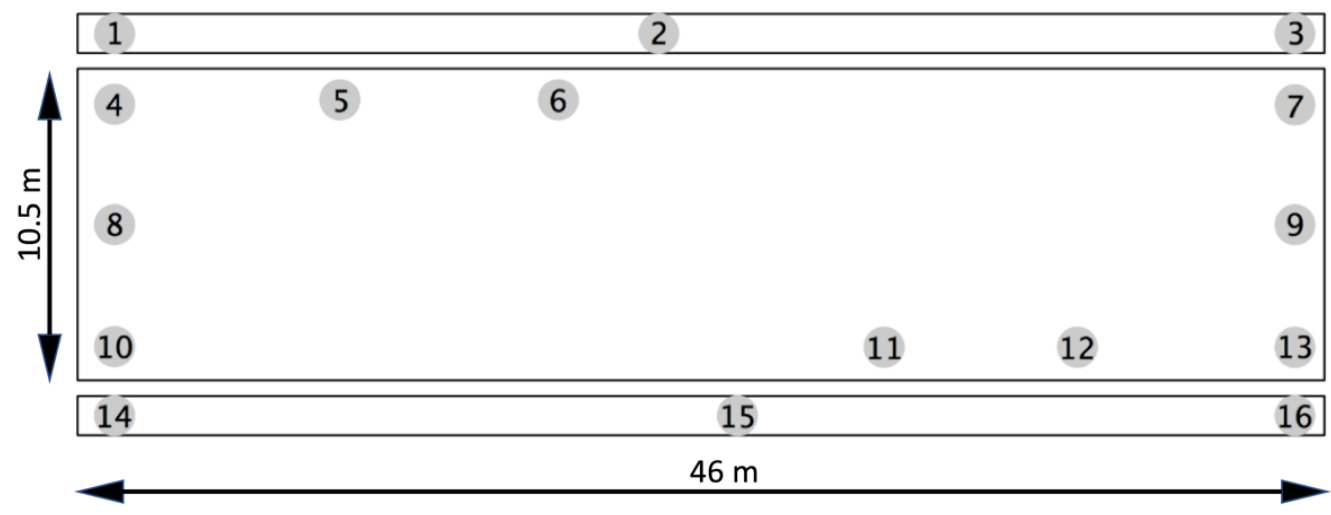

Fig. 8. Schematic top view of the Gislaved Bridge and sensor location. 


\section{RESULTS AND DISCUSSION}

\section{Measurement and Monitoring Results Sundbron Bridge}

Table 1. The Measured MC and Temperature during Three Measurement Occasions at Sundbron Bridge

\begin{tabular}{|c|c|c|c|c|c|c|c|c|c|}
\hline Date: & $06 / 12 / 15$ & & & $11 / 02 / 16$ & & & $28 / 06 / 16$ & & \\
\hline & $\begin{array}{c}0 \text { to } 45 \\
\text { (mm) }\end{array}$ & $\begin{array}{c}100 \\
\text { to } \\
515 \\
(\mathrm{~mm})\end{array}$ & $\begin{array}{c}\text { Temp } \\
\left({ }^{\circ} \mathrm{C}\right)\end{array}$ & $\begin{array}{c}0 \text { to } 45 \\
\mathrm{~mm}\end{array}$ & $\begin{array}{c}100 \\
\text { to } \\
515 \\
\mathrm{~mm}\end{array}$ & $\begin{array}{c}\text { Temp } \\
\left({ }^{\circ} \mathrm{C}\right)\end{array}$ & $\begin{array}{c}0 \text { to } 45 \\
\text { mm }\end{array}$ & $\begin{array}{c}100 \\
\text { to } \\
515 \\
\mathrm{~mm}\end{array}$ & $\begin{array}{c}\text { Temp } \\
\left({ }^{\circ} \mathrm{C}\right)\end{array}$ \\
\hline 1. Deck NW & 22.7 & 16.9 & 3 & 38.7 & 24.6 & 3 & $X^{*}$ & 16.6 & 17 \\
\hline 2. Deck N & 24.8 & 23.3 & 3 & 25.6 & 23.3 & 3 & 15.8 & 17.9 & 17 \\
\hline 3. Deck NE1 & 35.6 & 29.5 & 3 & 24.5 & 22.9 & 3 & 15.6 & 16.3 & 17 \\
\hline 4. Deck NE2 & 19.5 & 16.6 & 3 & 23.9 & 22.1 & 3 & 15.9 & 21.2 & 17 \\
\hline 5. Deck SW1 & 21.0 & 16.1 & 3 & 24.4 & 19.0 & 3 & 14.5 & 15.7 & 17 \\
\hline 6. Deck SW2 & 36.3 & 30.3 & 3 & 27.3 & 23.1 & 3 & 15.5 & 17.5 & 17 \\
\hline 7. Deck SE & 16.6 & 15.5 & 3 & 24.9 & 21.2 & 3 & 14.8 & 15.8 & 17 \\
\hline
\end{tabular}

The moisture content of Sundbron was measured three times, and the results are shown in Table 1. The first measurement was two weeks after the erection of the bridge; the measurement was taken in the evening with an ambient temperature of $-1{ }^{\circ} \mathrm{C}$ and overcast skies. During the erection, there was both snow and rain. The bridge deck was assembled on-site, one glulam beam at a time, and when all the beams were in place the tensioning rods were then stressed with a jack. The wet weather during the assembly of the bridge was the reason for the increased MC in the bridge deck. The second measurement was taken two months later, in the evening with an ambient temperature of $-1{ }^{\circ} \mathrm{C}$ and overcast skies. The third measurement was performed in June 2016 at noon with clear weather and $19{ }^{\circ} \mathrm{C}$. In Table 1 it can be seen that all MC values had dried down to acceptable levels in June 2016. The high MC measured in February 2016 prompted the monitoring of measurement point 1 at a depth of $0 \mathrm{~mm}$ to $45 \mathrm{~mm}$. An Omnisense S-16 sensor (OmniSense, Landys Island, SC, USA) was attached to the electrodes and logged the resistance and relative humidity $(\mathrm{RH})$ every hour. The battery-powered sensor has an on-board memory chip where the resistance values were saved. Because there was no internet connection at the bridge, a gateway using the $4 \mathrm{G}$ network was used to collect the data. The gateway was placed in a waterproof bag and placed close to the bridge during 
the data collection. The data were recorded every hour from February $2^{\text {nd }}$ until October $17^{\text {th }}$, and results are shown in Fig. 9. The high MC found in sensor 1 Deck NW is from water vapor from the water below, which condenses on the bridge deck. Moisture also was attributable to the conditions under which the bridge was assembled. The monitoring of the $\mathrm{MC}$ also show that the bridge deck dries down to acceptable levels during the spring and early summer, and a slight increase in $\mathrm{MC}$ in the fall as the $\mathrm{RH}$ is increasing.

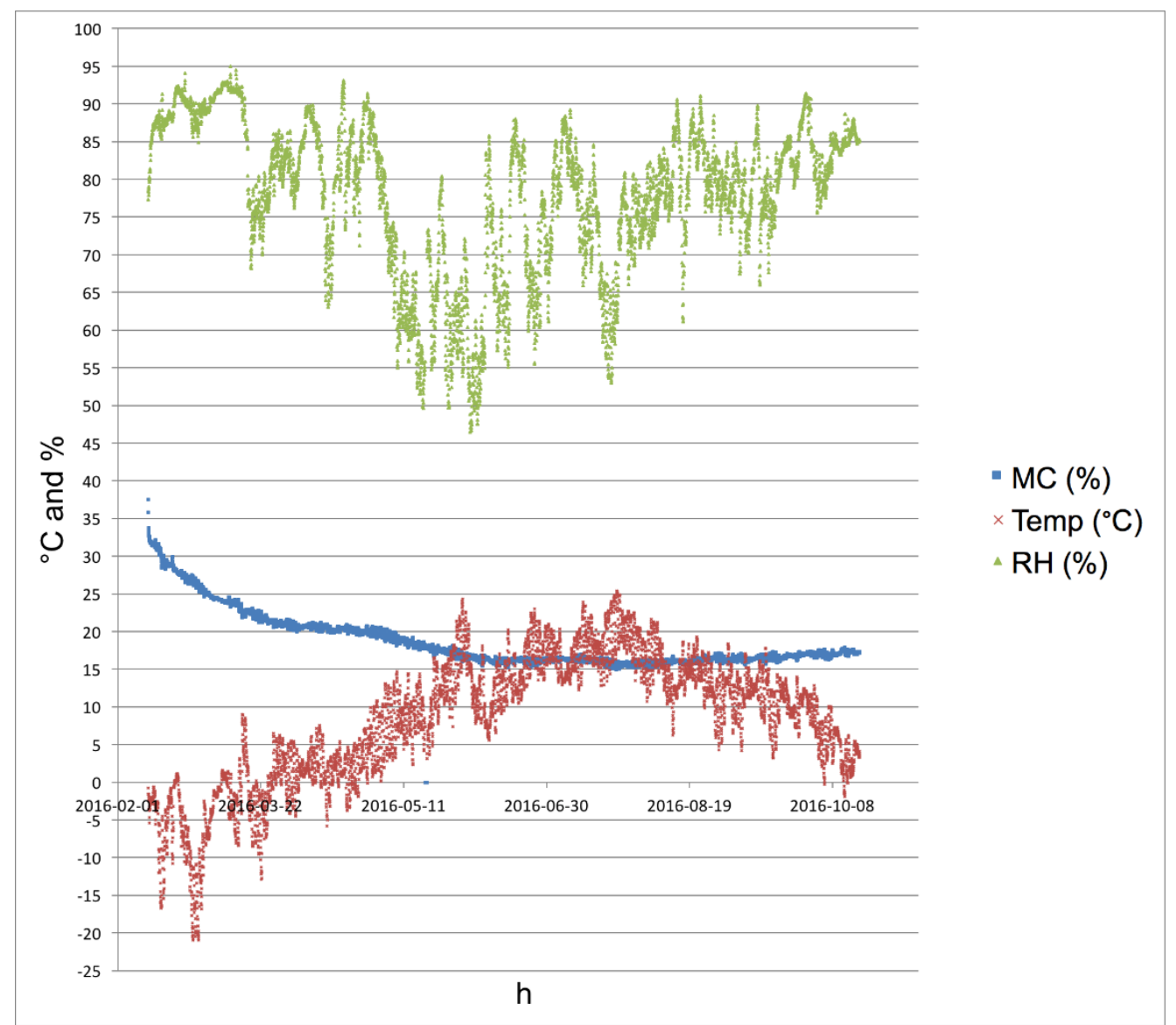

Fig. 9. Monitoring of point 1 at $45 \mathrm{~mm}$ depth at Sundbron; $\mathrm{MC}, \mathrm{RH}$, and temperature from February to October

\section{Gislaved Bridge}

The MC in the Gislaved Bridge was measured at the time of retrofitting, and seven months later. The results are shown in Table 2. The weather during both measurements was overcast with ambient temperatures of $8{ }^{\circ} \mathrm{C}$ and $11{ }^{\circ} \mathrm{C}$, respectively. The ambient temperature differs from the timber bridge temperature, since the timber adapts much slower to temperature changes. The bridge showed MC values close to the FSP at sensors 4, 5, 6, 10, and 11 (Table 2). Sensor 5, 6, and 11 are both located over water, and finding the high MC inside of the glulam beam would not have been possible during an inspection with conventional MC meters. The high values in the deck could be traced to a faulty design detail. The design detail was adjusted by the company that built the bridge to avoid any elevated MC in the future. 
Table 2. The Measured MC and Temperature during Two Measurement Occasions at Gislaved Bridge

\begin{tabular}{|c|c|c|c|c|c|c|}
\hline Date: & $28 / 10 / 15$ & & & $18 / 05 / 16$ & & \\
\hline & $\begin{array}{c}0 \text { to } \\
45 \mathrm{~mm}\end{array}$ & $\begin{array}{c}100 \text { to } \\
450 \mathrm{~mm}\end{array}$ & $\begin{array}{c}\text { Temp } \\
\left({ }^{\circ} \mathrm{C}\right)\end{array}$ & 0 to $45 \mathrm{~mm}$ & $\begin{array}{r}100 \text { to } \\
450 \mathrm{~mm}\end{array}$ & Temp $\left({ }^{\circ} \mathrm{C}\right)$ \\
\hline 1. Arch NW & 19.6 & 17.3 & 7 & 25.2 & 19.4 & 10 \\
\hline 2. Arch N & 16.3 & 15.8 & 7 & 19.7 & 16.9 & 10 \\
\hline 3. Arch NE & 21.6 & 19.9 & 7 & 23.6 & 22.6 & 10 \\
\hline 4. Deck NW1 & 26.4 & 28.5 & 7 & 28.5 & 27.3 & 10 \\
\hline 5. Deck NW2 & 21.7 & 19.6 & 7 & 24.7 & 25.5 & 10 \\
\hline 6. Deck NW3 & 21.0 & 29.8 & 7 & 21.9 & 27.3 & 10 \\
\hline 7. Deck NE & 21.2 & 23.2 & 7 & 21.5 & 25.1 & 10 \\
\hline 8. Deck W & 21.2 & 18.4 & 7 & 21.5 & 20.4 & 10 \\
\hline 9. Deck E & 18.4 & 19.0 & 7 & 19.6 & 21.0 & 10 \\
\hline 10. Deck SW & 23.8 & 24.5 & 7 & 27.1 & 27.3 & 10 \\
\hline 11. Deck SE1 & 24.8 & 19.6 & 7 & 32.2 & 23.1 & 10 \\
\hline 12. Deck SE2 & 22.6 & 18.4 & 7 & 27.4 & 19.9 & 10 \\
\hline 13. Deck SE3 & 20.9 & 22.0 & 7 & 21.5 & 23.5 & 10 \\
\hline 14. Arch SW & 19.8 & 20.4 & 7 & 24.9 & 23.5 & 10 \\
\hline 15. Arch S & 19.5 & 17.5 & 7 & 20.2 & 19.5 & 10 \\
\hline 16. Arch SE & 20.9 & 18.4 & 7 & 22.1 & 21.0 & 10 \\
\hline
\end{tabular}

\section{CONCLUSIONS}

1. The sensor presented in this work is passive, robust, scalable, simple, cheap, and built to last the service life of the bridge. The measurements were based on a well-proven method of determining MC in wood- resistance measurements, but with adjustments made for the length of the uninsulated electrodes. It is important that the sensor is installed at points of special concern, e.g. at the end of the bridge decks and close to attachment points for rail posts. Since the sensor is passive, there is no need for energy supply at the bridge. Measurements are taken with handheld devices. If there is a need for monitoring a battery powered logger is easily installed in the junction box and can provide data for several years before the need of battery replacement.

2. Mounting the sensors during the final stage of production was a quick procedure with little to no interference with the production. However, there was a need for extra caution during transportation if the junction boxes were mounted at the factory. They would need wood blocks that protect them from damage.

3. The most important aspect of monitoring or measuring the $\mathrm{MC}$ in a timber bridge was to find high levels of MC, evaluate why there was an increase, and prevent it from occurring again. The presented sensor system found high MC levels in the Gislaved Bridge. The increased $\mathrm{MC}$ was found at the mid-height of the cross-section. If the bridge had not been equipped with this sensor system, the leak would probably not have been found until the next in-depth inspection, which was scheduled for 2019. As a result of the sensor, the flawed construction detail could be corrected immediately and the manufacturer's design updated for future bridges.

4. The Gislaved Bridge took two days to retrofit with 16 sensors. Considering that it was a large bridge with tall arches, and the number of sensors that were mounted, the 
retrofitting was quite fast. For bridges without arches, the retrofitting could be completed even faster.

5. The long-term monitoring of Sundbron showed that, after the bridge's wet start during the assembly, the surface moisture on the bottom of the bridge deck dried down to normal MC levels in the spring. The end of 2015 was mild and the water below the bridge had not frozen, which caused water vapor from the strait to condensate on the bottom of the bridge, together with the weather during the on-site assembly caused the initial high MC.

\section{ACKNOWLEDGMENTS}

The financial support from the Swedish Research Council Formas project, Experimental studies of capillary phenomena in bio-based materials 942-2016-64, is gratefully acknowledged.

\section{REFERENCES CITED}

Anon (2004). "Vägar och gators utformning," [“Configuration of roads and streets"] (VV Publikation 2004:80), Swedish Transport Administration, Borlänge, Sweden.

Björngrim, N., Fjellström, P. A., and Hagman, O. (2017). "Resistance measurements to find high moisture content inclusions adapted for large timber bridge cross-sections," BioResources 12(2), 3570-3582. DOI: 10.15376/biores.12.2.3570-3582

Björngrim, N., Hagman, O., and Wang, X. A. (2016). "Moisture content monitoring of a timber footbridge," BioResources 11(2), 3904-3913. DOI:

10.15376/biores.11.2.3904-3913

Dyken, T., and Klepp, H. (2010). "Monitoring the moisture content of timber bridges," in: Proceedings of the International Conference on Timber Bridges, Lillehammer, Norway, pp. 223-236.

Fjellström, P. A., and Just, A. (2017). "Investigation of timber bridges in Estonia," in: The 3rd International Conference on Timber Bridges, Skellefteå, Sweden.

Ross, R. J. (2010). Wood Handbook: Wood as an Engineering Material, US Dept. Agriculture, Forest Products Laboratory, General Technical Report FPL-GTR-190.

Tannert, T., Müller, A., and Vogel, M. (2010). "Structural health monitoring of timber bridges," in: Proceedings of the International Conference on Timber Bridges, Lillehammer, Norway, pp. 205-212.

Viitanen, H. (1994). "Factors affecting the development of Biodeterioration in wooden constructions," Materials and Structures 27(8), 483-493.

Article submitted: January 19, 2017; Peer review completed: March 12, 2017; Revised version received and accepted: July 11, 2017; Published: August 16, 2017.

DOI: $10.15376 /$ biores.12.4.7218-7227 